\title{
Effects of nitrous oxide on minimum alveolar concentration of desflurane in dogs
}

[Efeitos do óxido nitroso sobre a concentração alveolar mínima do desfluorano, em cães]

\author{
C.T. Nishimori ${ }^{1}$, N. Nunes ${ }^{1 *}$, D.P. Paula ${ }^{1}$, M.L. Rezende ${ }^{2}$, A.P. Souza ${ }^{3}$, P.S.P. Santos ${ }^{4}$ \\ ${ }^{1}$ Faculdade de Ciências Agrárias e Veterinárias - UNESP \\ Via de Acesso Prof. Paulo Donato Castellane s/n \\ 14884-900 - Jaboticabal, SP \\ ${ }^{2}$ Médica veterinária - autônoma \\ ${ }^{3}$ Universidade Federal de Campina Grande - Patos, PB \\ ${ }^{4}$ Centro Universitário Barão de Mauá - Ribeirão Preto, SP
}

\begin{abstract}
Effects of nitrous oxide $\left(\mathrm{N}_{2} \mathrm{O}\right)$ on minimum alveolar concentration (MAC) of desflurane were studied. For that purpose, 30 dogs were randomly allocated into two groups: desflurane group (GD) and $\mathrm{N}_{2} \mathrm{O}$ and desflurane group (GDN). GD animals received propofol to intubation, and $11.5 \mathrm{~V} \%$ of desflurane diluted in $100 \% \mathrm{O}_{2}$. After 30 minutes, they received electric stimulus and if the animal did not react to stimulus, desflurane concentration was reduced by $1.5 \mathrm{~V} \%$. This protocol was repeated at each 15 minutes, and stimulus was interrupted when voluntary reaction was observed. GDN dogs were submitted to diluent flow $30 \% \mathrm{O}_{2}$ and $70 \%$ $\mathrm{N}_{2} \mathrm{O}$. Desflurane's MAC; heart (HR) and respiratory (RR) rates; systolic, diastolic and mean arterial pressures (SAP, DAP, and MAP, respectively); end tidal carbon dioxide $\left(\mathrm{ETCO}_{2}\right)$; oxyhemoglobin saturation $\left(\mathrm{SpO}_{2}\right)$ and body temperature (T) were evaluated. In both groups increase in $\mathrm{HR}$ and $\mathrm{ETCO}_{2}$, and decrease in RR and T were associated with administration of the highest dose of desflurane. Blood pressures decreased 30 minutes after desflurane administration in GDN, and after this measurement the values increased. Reduction in desflurane's MAC was observed as well. It is concluded that $\mathrm{N}_{2} \mathrm{O}$ associated with desflurane reduced desflurane's MAC by $16 \%$ with increase in HR and respiratory depression.
\end{abstract}

Keywords: dog, desflurane, nitrous oxide, MAC

\section{RESUMO}

Estudaram-se os efeitos do óxido nitroso $\left(\mathrm{N}_{2} \mathrm{O}\right)$ sobre a concentração alveolar mínima (CAM) do desfluorano. Trinta cães foram distribuidos em dois grupos: desfluorano (GD) e $\mathrm{N}_{2} \mathrm{O}$ e desfluorano (GDN). Os do GD receberam propofol $(8,9 \pm 1,65 \mathrm{mg} / \mathrm{kg}$ ) para intubação orotraqueal e após, $11,5 \mathrm{~V} \%$ de desfluorano em $100 \%$ de $\mathrm{O}_{2}$. Após 30 minutos, os animais receberam estímulo elétrico e não havendo reação do animal, reduziu-se a concentração em 1,5V\%. Repetiu-se o protocolo a cada 15 minutos, cessando-se os estímulos quando observada reação voluntária. Os GDN foram submetidos a mesmo protocolo, substituindo-se o fluxo diluente por 30\% $\mathrm{O}_{2}$ e 70\% $\mathrm{N}_{2} \mathrm{O}$. Mensuraram-se freqüências cardiaca $(F C)$ e respiratória (FR), pressões arteriais sistólica, diastólica e média (PAS, PAD e PAM), concentração de dióxido de carbono ao final da expiração $\left(E_{2} \mathrm{CO}_{2}\right)$, saturação de oxihemoglobina $\left(\mathrm{SpO}_{2}\right)$, temperatura corpórea (TC) e a CAM do desfluorano. Observou-se aumento da $\mathrm{FC}$, ETCO $\mathrm{ESpO}_{2}$, e redução da $\mathrm{FR}$ e da TC concomitantemente à administração da maior dose de desfluorano, além de redução da CAM do desfluorano. As pressões arteriais diminuíram em M30 aumentando posteriormente. Concluiu-se que o $\mathrm{N}_{2} \mathrm{O}$ associado ao desfluorano reduz em 16\% a CAM do anestésico volátil. Além disso, essa associação promoveu aumento da FC e depressão respiratória.

Palavras-chave: cão, desfluorano, óxido nitroso, CAM

Recebido em 4 de novembro de 2005

Aceito em 11 de novembro de 2006

*Autor para correspondência (corresponding author)

E-mail: newton@fcav.unesp.br

Apoio: FAPESP 


\section{INTRODUCTION}

Balanced anesthetic techniques that minimize adverse physiologic alterations of patients have been an important field of study in anesthesiology. Particulary reduction of minimum alveolar concentration of inhalant anesthetic has been studied.

Desflurane is a halogenated anesthetic agent that presents anesthetic effect only in high concentrations, around $7.5 \mathrm{~V} \%$ in dogs and 6 to $7 \mathrm{~V} \%$ in humans (Eger II, 1992). This agent depresses spontaneous ventilation in humans, with a dose dependent decrease in minute ventilation and an increase in respiratory rate (RR) (Lockhart et al., 1991). At cardiovascular system, desflurane causes dose dependent reduction in arterial pressure, resulting from decrease in systemic vascular resistance (Grundmann et al., 1996). It increases heart rate due to vagal inhibition (Picker et al., 2003) associated to activation of the sympathetic activity (Zwass et al., 1992; Clarke et al., 1996a; Park, 2002). Moreover, some studies have shown that desflurane may result in a more potent cardioprotective effect than the other volatile anesthetics (Piriou et al., 2002; Haelewyn et al., 2004).

Minimum alveolar concentration (MAC) of desflurane varies among species and individuals from same species (Eger II et al., 1988). In adult humans, desflurane MAC varies from 6.0 to $7.25 \mathrm{~V} \%$, while in elderly patients is $5.17 \mathrm{~V} \%$ (Gold et al., 1993) and in children is 10V\% (Eger II, 1992). Several factors as advanced age, hypothermia and depressive drugs, such as midazolam, fentanyl and nitrous oxide $\left(\mathrm{N}_{2} \mathrm{O}\right)$, can reduce MAC (Eger II, 1992). Association of fentanyl with droperidol allowed a $40 \%$ reduction in desflurane MAC in dogs (Nunes et al., 2001). Rezende et al. (2004) observed that premedication with levomepromazine allowed desflurane MAC to be reduced by $40 \%$, and also contributed to respiratory stability. Allaouchiche et al. (2001) observed that desflurane MAC is significantly decreased in a normotensive septic porcine model.

In humans there are many reports regarding reduction in MAC related to age. Fisher and Zwass (1992) studied effects of nitrous oxide in children submitted to anesthesia with desflurane and they obtained a decrease of $25 \%$ in MAC. Rampil et al. (1991) observed a reduction around $50 \%$ in adults, and Gold et al. (1993) described a $70 \%$ decrease in elderly patients' MAC.

Nitrous oxide is a colorless gas, nonirritant, with sweetened odor, neither inflammable nor explosive. This gas is an excellent analgesic, exempt of hypnotic properties; therefore it does not induce a deep anesthetic plan. It is potent enough to promote analgesia correspondent to 10-15mg of morphine (Stenqvist et al., 2001). Its administration is recommended with at least $30 \%$ of oxygen (Wylie and Churchill-Davidson, 1974).

Nitrous oxide causes depression in diaphragmatic contractility, due to changes on distribution and regulation of nervous impulses in respiratory muscles (Warner et al., 1998). Thus, its use should be avoided in patients with preexistent respiratory or neurologic diseases (Fauroux et al., 2002).

Although this anesthetic gas has a direct depressive effect on myocardium, this can be compensated by indirect sympathetic activation (Hohner and Reiz, 1994), which might contribute to increase of incidence of cardiac arrhythmias (Steffey, 1996).

It has been reported that association of $\mathrm{N}_{2} \mathrm{O}$ with a more potent inhalant anesthetic allows a reduction in its concentration requirement and, consequently, reduces side effects on cardiovascular and respiratory systems (Steffey, 1996). Patel and Goa (1995) observed that the use of $60 \%$ of $\mathrm{N}_{2} \mathrm{O}$ reduced MAC of desflurane by about $45-53 \%$ in adults, $68 \%$ in aged patients (over 65 years old) and 22-26\% in children.

Data referring to possible interferences of $\mathrm{N}_{2} \mathrm{O}$ on desflurane's MAC in dogs are scarce. Thus, the aim of this study was to evaluate possible effects of $\mathrm{N}_{2} \mathrm{O}$ on desflurane's MAC in dogs.

\section{MATERIAL AND METHODS}

Thirty healthy mixed breed adult dogs, males and females, fed on commercial diet were used. Dogs were randomly allocated into two groups of 15 animals each (GD, desflurane group, and GDN, 
$\mathrm{N}_{2} \mathrm{O}$ and desflurane group). Weight of animals were $9.4 \pm 2.6 \mathrm{~kg}(\mathrm{GD})$ and $11.3 \pm 2.8 \mathrm{~kg}(\mathrm{GDN})$.

Induction of anesthesia was performed with intravenous propofol $\quad\left(8.9 \pm 1.65 \mathrm{mg} \cdot \mathrm{kg}^{-1}\right.$; Diprivan $\left.^{1}\right)$. After orotracheal intubation, animals of GD were maintained with desflurane (Suprane) $^{1}$, diluted in $100 \%$ of $\mathrm{O}_{2}$, in a total flow of $30 \mathrm{ml} \cdot \mathrm{kg}^{-1} \cdot \mathrm{min}^{-1}$, using a semiclosed circle system $(210 \mathrm{SE})^{2}$, with a calibrated vaporizer $(\text { TEC } 6)^{2}$.

Initially, desflurane was supplied in concentration of 1.6 MAC, considering 1 MAC equal to $7.2 \mathrm{~V} \%$ (5), which was measured at end of expiration through digital equipment (RGM $5250)^{2}$. This equipment was calibrated before each use, and its sensor was placed at the end of orotracheal tube, connected to the anesthetic circuit. Thirty minutes after starting desflurane administration, dogs were submitted to an electric impulse of alternate current with $30 \mathrm{~Hz}$ and $200 \mathrm{~V}$, current intensity of $4 \mathrm{~mA}$ and duration of 5 seconds, using an electrostimulator ${ }^{3}$. Electrical impulses were applied through two electrodes connected to needles that were introduced in the oral mucous membrane of the dogs. Needles were positioned close to canine and first pre molar teeth, as described by Nunes et al. (2001), having attention to identify any voluntary movement of head, neck or limbs, which were indicative of discomfort.

At the end of stimulus, if voluntary response was not observed, bag reservoir was emptied and concentration of desflurane was reduced by $1.5 \mathrm{~V} \%(0.2 \mathrm{MAC})$. Anesthetic circuit was saturated with new concentration of gaseous mixture (desflurane diluted in $100 \%$ of $\mathrm{O}_{2}$ ) and 15 minutes after administration of this new anesthetic concentration, a new electric charge was applied, with same frequency, tension, intensity and duration.

Electric impulses were interrupted when a voluntary reaction of the animal was observed. MAC value was considered to be the mean concentration between the dose of desflurane that allowed the observation of voluntary movement

\footnotetext{
1 Zeneca Farmacêutica do Brasil Ltda., São Paulo, SP, Brazil

2 Ohmeda mod. Excel, Datex, Madison, USA

${ }^{3}$ Eletroestimulador Tonus PDS, Dolsch Ltda., Porto Alegre, RS, Brazil
}

and the dose previously used, as established by Valverde et al. (1989). For GDN animals, the same methodology was used, but the diluent flow was $30 \% \mathrm{O}_{2}$ and $70 \% \mathrm{~N}_{2} \mathrm{O}$.

In order to minimize effects of body temperature on MAC, it was maintained between 37.8 and $39.0^{\circ} \mathrm{C}$, through a heating $\mathrm{pad}^{4}$.

During anesthetic procedure, heart rate (HR) was evaluated through a computerized electrocardiograph ${ }^{5}$. Systolic, diastolic and mean arterial pressures (SAP, DAP and MAP, respectively) were evaluated through invasive method, after femoral artery catheterization, in computerized digital monitor ${ }^{6}$. Respiratory rate $(\mathrm{RR})$, end tidal carbon dioxide $\left(\mathrm{ETCO}_{2}\right)$ and oxyhemoglobin saturation $\left(\mathrm{SpO}_{2}\right)$ were obtained through direct reading on a multiparametric monitor (RGM 5250) $)^{2}$. Body temperature (T) was measured using a clinical thermometer placed in the rectum.

Measurements were made at the baseline moment (M0), and 30 (M30), 45 (M45) and 60 (M60) minutes after anesthetic induction, always before the use of electric impulses. Measurements were also performed at 75 (M75), 90 (M90), and 105 (M105) minutes after induction, when it was possible.

The statistical analysis of clinical variables was made using analysis of variance, and the comparison of mean values of desflurane MAC between groups was accomplished by Student $t$ test. The level of significance was considered at 0.05 .

\section{RESULTS}

Regarding MAC, there was difference between groups as GDN animals presented lower means $(6.8 \pm 1.2)$ when compared to group of animals that received only desflurane (8.1 \pm 1.0$)$ (Fig. 1).

Heart rate significantly increased when the administration of desflurane was initiated. In $\mathrm{GD}$, this effect was seen at all time points during the anesthetic period, when compared to control data. But, in GDN, the values continued to increase until the end of the evaluation period (Table 1).

\footnotetext{
${ }^{4}$ Gaymar mod. TP-500, London, England

${ }^{5}$ TEB mod. ECGPC software version 1.10, São Paulo, SP, Brazil

${ }^{6}$ DIXTAL mod. DX 2010, Manaus, AM, Brasil
} 


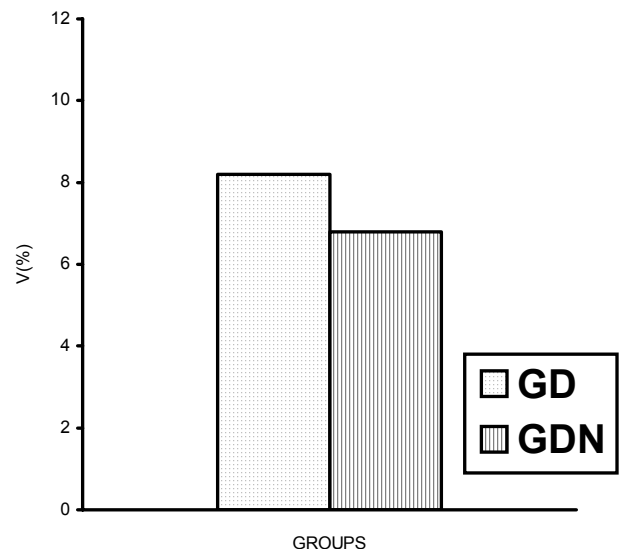

Figure 1. Variation of the mean values of minimum alveolar concentration $(\mathrm{V} \%)$ in dogs anesthetized with desflurane, associated (GDN) or not (GD) with nitrous oxide.

In GD, SAP does not demonstrate difference when compared to M0, but in GDN, this variable decreased after administration of desflurane. After this measurement, the values increased and returned to the baseline values. Regarding DAP, there were difference between groups at M0. In GD, there was not difference when compared to M0. In GDN it was observed increase from $69 \pm 9$ to $83 \pm 11 \mathrm{mmHg}$ at M60 when compared to M0. The MAP does not demonstrate difference when compared to M0 in GD. In GDN, this parameter increased from $91 \pm 10$ to $107 \pm 14 \mathrm{mmHg}$ at $\mathrm{M} 60$ when compared to M0 (Table 1).

In both groups, respiratory rate decreased since the beginning of administration of anesthetic agents. At the end of the evaluation period (M60), RR had returned to the reference range. End tidal $\mathrm{CO}_{2}$ at 60 minutes of anesthesia was $33 \pm 8$ and $42 \pm 9 \mathrm{mmHg}$ in GD and GDN groups, respectively, and this difference was statistically different. The $\mathrm{ETCO}_{2}$ in GD group increased significantly from $28 \pm 6$ to $44 \pm 13 \mathrm{mmHg}$ and $37 \pm 9 \mathrm{mmHg}$ at 30 and 45 minutes, respectively. In $\mathrm{GDN}, \mathrm{ETCO}_{2}$ increased significantly from $31 \pm 6$ to $46 \pm 18 \mathrm{mmHg}$ and $41 \pm 16 \mathrm{mmHg}$ at 30 and 45 minutes, respectively.

Table 1. Mean values and standard deviation $(\overline{\mathrm{X}} \pm \mathrm{s})$ of heart rate (HR), systolic, diastolic and mean arterial pressures (SAP, DAP, and MAP, respectively), respiratory rate (RR), end tidal carbon dioxide $\left(\mathrm{ETCO}_{2}\right)$, oxyhemoglobin saturation $\left(\mathrm{SpO}_{2}\right)$ and body temperature $(\mathrm{T})$ in dogs anesthetized with decreasing doses of desflurane, associated (GDN) or not (GD) to nitrous oxide during a period of 60 minutes

\begin{tabular}{cccccc}
\hline \multirow{2}{*}{ Variable } & Group & M0 & M30 & M45 & M60 \\
\cline { 3 - 5 } & & $0.0 \mathrm{~V} \%$ & $11.5 \mathrm{~V} \%$ & $10.0 \mathrm{~V} \%$ & $8.5 \mathrm{~V} \%$ \\
\hline \multirow{2}{*}{ HR (beats/min) } & GD & $111 \pm 19 \mathrm{a}$ & $132 \pm 23 \mathrm{~b}$ & $133 \pm 21 \mathrm{~b}$ & $134 \pm 22 \mathrm{~b}$ \\
& GDN & $115 \pm 20 \mathrm{a}$ & $133 \pm 20 \mathrm{~b}$ & $139 \pm 22 \mathrm{c}$ & $143 \pm 24 \mathrm{c}$ \\
SAP $(\mathrm{mmHg})$ & GD & $131 \pm 17 \mathrm{ab}$ & $122 \pm 30 \mathrm{a}$ & $130 \pm 29 \mathrm{a}$ & $138 \pm 30 \mathrm{~b}$ \\
& GDN & $125 \pm 11 \mathrm{bc}$ & $110 \pm 20 \mathrm{a}$ & $125 \pm 19 \mathrm{~b}$ & $139 \pm 19 \mathrm{c}$ \\
DAP $(\mathrm{mmHg})$ & GD & $79 \pm 14 \mathrm{bc}$ & $69 \pm 25 \mathrm{a}$ & $75 \pm 22 \mathrm{~b}$ & $82 \pm 19 \mathrm{c}$ \\
& GDN & $69 \pm 9 \mathrm{ab}$ & $61 \pm 15 \mathrm{a}$ & $75 \pm 14 \mathrm{~b}$ & $83 \pm 11 \mathrm{c}$ \\
$\mathrm{MAP}(\mathrm{mmHg})$ & GD & $99 \pm 15 \mathrm{bc}$ & $89 \pm 26 \mathrm{a}$ & $97 \pm 25 \mathrm{~b}$ & $105 \pm 23 \mathrm{c}$ \\
& GDN & $91 \pm 10 \mathrm{ab}$ & $82 \pm 16 \mathrm{a}$ & $96 \pm 15 \mathrm{~b}$ & $107 \pm 14 \mathrm{c}$ \\
$\mathrm{RR}(\mathrm{breaths} / \mathrm{min})$ & GD & $28 \pm 10 \mathrm{c}$ & $15 \pm 8 \mathrm{a}$ & $21 \pm 18 \mathrm{~b}$ & $26 \pm 21 \mathrm{bc}$ \\
& GDN & $23 \pm 6 \mathrm{c}$ & $11 \pm 6 \mathrm{a}$ & $16 \pm 8 \mathrm{~b}$ & $19 \pm 9 \mathrm{bc}$ \\
$\mathrm{ETCO}_{2}(\mathrm{mmHg})$ & GD & $28 \pm 6 \mathrm{a}$ & $44 \pm 13 \mathrm{c}$ & $37 \pm 9 \mathrm{~b}$ & $33 \pm 8 * \mathrm{~b}$ \\
& GDN & $31 \pm 6 \mathrm{a}$ & $46 \pm 18 \mathrm{c}$ & $41 \pm 16 \mathrm{~b}$ & $42 \pm 9 \mathrm{bc}$ \\
$\mathrm{SpO}_{2}(\%)$ & GD & $97 \pm 2 \mathrm{a}$ & $100 \pm 0.3 * \mathrm{~b}$ & $100 \pm 0 * \mathrm{~b}$ & $99 \pm 1 \mathrm{~b}$ \\
& GDN & $98 \pm 1.7 \mathrm{a}$ & $99 \pm 0.8 \mathrm{~b}$ & $99 \pm 1.2 \mathrm{~b}$ & $99 \pm 1.2 \mathrm{~b}$ \\
$\mathrm{~T}\left({ }^{\circ} \mathrm{C}\right)$ & GD & $39.3 \pm 0.6 \mathrm{c}$ & $38.3 \pm 0.4 \mathrm{~b}$ & $38.2 \pm 0.5 \mathrm{a}$ & $38.2 \pm 0.5 \mathrm{ab}$ \\
& GDN & $39.1 \pm 0.5 \mathrm{c}$ & $38.0 \pm 0.5 \mathrm{~b}$ & $37.9 \pm 0.6 \mathrm{a}$ & $38.0 \pm 0.7 \mathrm{ab}$ \\
\hline
\end{tabular}

*Statistically difference between groups $(\mathrm{P}<0.05) . \mathrm{M}=$ moment

Different letters denote differences occurring with time within the same group $(\mathrm{P}<0.05)$.

M0 to M60: moments from 0 to 60 minutes after anesthetic induction. 
$\mathrm{SpO}_{2}$ showed significant changes during anesthesia. In both groups, an increase in $\mathrm{SpO}_{2}$, when compared to control values was seen at all time points during the anesthetic procedure. At M0, no difference between groups was observed. However, after the anesthetic administration, a significant difference between the two groups was noticed at $30(\mathrm{GD}=100 \pm 0.3>\mathrm{GDN}=99 \pm 0.8)$ and 45 minutes $(\mathrm{GD}=100 \pm 0>\mathrm{GDN}=99 \pm 1.2)$, with GD having greater values when compared to GDN.

In both groups, body temperature decreased since the beginning of administration of anesthetic agents. In GD, this parameter decreased from $39.3 \pm 0.6$ to $38.2 \pm 0.5^{\circ} \mathrm{C}$, and in GDN from $39.1 \pm 0.5$ to $38.0 \pm 0.7^{\circ} \mathrm{C}$ in $\mathrm{M} 60$ when compared to M0 (Table 1).

\section{DISCUSSION}

MAC is defined as minimum alveolar concentration of a volatile anesthetic at one atmosphere of pressure that produces immobility in $50 \%$ of subjects exposed to a supramaximal noxious stimulus (Steffey, 1996). Some factors as age (Nickalls and Mapleson, 2003), administration of drugs and body temperature can influence MAC reduction (Eger II, 1992; Hammond et al., 1994; Amaral, 2001).

Analysis of the results demonstrated that there was interference of $\mathrm{N}_{2} \mathrm{O}$ on desflurane MAC, since the group anesthetized with association of desflurane and $\mathrm{N}_{2} \mathrm{O}$ presented a reduction of $16 \%$ in this variable, when compared to the other group. This finding was probably a result of potentialization of halogenated anesthetic produced by $\mathrm{N}_{2} \mathrm{O}$, probably due to its analgesic effect (Stenqvist et al., 2001). An important factor to be considered, regarding the great difference in reduction of MAC between humans and dogs, is the anesthetic potency of $\mathrm{N}_{2} \mathrm{O}$ in both species. In humans, MAC for $\mathrm{N}_{2} \mathrm{O}$ is about $104 \mathrm{~V} \%$ (Hornbein et al., 1982), whereas in dog it is around $222 \mathrm{~V} \%$ (Eger II et al., 1965). Maybe this is one of possible reasons for that difference.

As the value of MAC reduction obtained in this study did not differ from those referred by Hammond et al. (1994), who noticed a reduction of desflurane MAC around $20 \%$ using $50 \% \mathrm{~N}_{2} \mathrm{O}$, it could be deduced that concentrations higher than $50 \%$ does not present considerable advantages in decrease of desflurane MAC in dogs.

Increase in HR concomitant to administration of desflurane is in accordance with findings of Clarke et al. (1996b) and Park (2002), who described this effect as a consequence of sympathomimetic activity of desflurane (Zwass et al., 1992). These findings are in agreement with those from Clarke et al. (1996a), who affirmed that variation in HR during anesthesia with desflurane is not dose dependent. Due to sympathomimetic effects of nitrous oxide (Hohner and Reiz, 1994; Mutoh et al., 2001), an additive effect in increase in HR in GDN could be expected when compared to isolated administration of desflurane. However, this phenomenon was not observed, since mean values were similar in both groups. In GDN, HR increased progressively at M45 and M60, when compared to the initial period of anesthetic administration. This phenomenon coincided with reduction of desflurane concentration, suggesting that high concentration of this anesthetic agent could be inhibiting sympathomimetic action of $\mathrm{N}_{2} \mathrm{O}$. With administration of lower doses, it was possible to observe additive effect of both agents, resulting in increase of these values during experimental period.

Analyzing the blood pressures, the animals of GD demonstrated DAP greater than GDN in the baseline moment. This difference was probably due to the animals of GDN had DAP values smaller than GD animals in the baseline moment. This result could suggest that it did not have possible influences of the studied drugs. Regarding the groups, in GD, the arterial pressures in M30 decreased when compared with baseline measurement. Although these results were not significant, they occurred when the higher concentration of desflurane was administered (Park, 2002; Kerbaul et al., 2004). In GDN, the same reduction was observed at M30. From this measurement, the arterial pressures had tendency to progressively return to baseline values along the experimental period. The reduction of blood pressure could be due to depression of myocardium contractility caused by the administration of high concentrations of desflurane associated to nitrous oxide, as described by Cahalan et al. (1991) and Sponheim et al. (2003). In addition, a reduction on systemic 
vascular resistance (Grundmann et al., 1996) caused by inhalatory agents could be associated to blood pressure depression.

Regarding RR, it was evident that the action of desflurane on this parameter is dose dependent, since mean values at M30 in both groups, which correspond to the highest concentration of desflurane, was lower than the other timepoints. From this moment on, RR behaved upwardly, as concentrations of volatile agent decreased, according to Patel and Goa (1995) and Steffey (1996). Clarke et al. (1996a) obtained similar findings in dogs anesthetized with different doses of desflurane, where RR showed lower values at $15 . \mathrm{V} \%$ than at $12.9 \mathrm{~V} \%$ of desflurane, demonstrating interference of anesthetic concentration on this variable.

Although nitrous oxide depresses respiratory centers (Amaral, 2001), and causes depression of diaphragmatic contratility (Fauroux et al., 2002) in a dose dependent manner, in this study it could be noticed that even when maintaining high concentrations of $\mathrm{N}_{2} \mathrm{O}$ in a constant way during all experiment, RR increased gradually from M30. This suggests that decreasing on this parameter was mainly caused by the highest concentration of desflurane used, indicating that this inhalant agent is a respiratory depressant (Nunes et al., 2003) as well as $\mathrm{N}_{2} \mathrm{O}$.

$\mathrm{ETCO}_{2}$ behaved in an inverse way, proportional to $R R$, as expected, since they present a close correlation. However, in spite of increase in RR values, $\mathrm{ETCO}_{2}$ in GDN were higher than those from GD at M60. This phenomenon can be explained by eventual depression of diaphragmatic contratility caused by nitrous oxide (Fauroux et al., 2002). In both groups, increase in $\mathrm{ETCO}_{2}$ in $\mathrm{M} 30$ coincided with the period of the highest desflurane concentration, which is in accordance with previous investigations carried out by Nunes et al. (2001) and Steffey (1996). After this period, $\mathrm{ETCO}_{2}$ returned to baseline values, concomitant with reduction of the anesthetic concentrations, due to minor depressive effect on respiratory system caused by the administration of lower doses of anesthetic (Clarke et al., 1996a; Nunes et al., 2001). These fact demonstrated correlation of $\mathrm{ETCO}_{2}$ with desflurane MAC, which is in accordance with the findings of McMurphy and Hodgson (1996), who studied effects of capnometry in cats anesthetized with desflurane and noticed that with 1.7MAC, arterial pressure of carbon dioxide presented higher values when compared to $1.3 \mathrm{MAC}$.

Oxymetry reflects percentage of hemoglobin saturated by oxygen, determinating a high degree of previsibility of tissue hypoxia, which allows reduction in index of anesthetic accidents related to hypoxemia (Nunes, 2002) mainly due to hypoventilation, which could interfere with MAC. Thus, those differences observed between groups at M30 and M45 have a questionable clinic value, because beyond means being similar, these values were inside the normal range for species (Moyle et al., 1994). Individual evaluation of groups showed an increase of mean values in both through experimental period. However, the same considerations made when interpretating results between groups can be repeated. In addition, variations found could be related to high concentration of oxygen provided to animal during anesthetic period, when compared to the concentration of oxygen in environment. Thus, as $\mathrm{SpO}_{2}$ was maintained between 97 and $100 \%$, it is possible to conclude that hypoxemia did not occur and, hence, there was no interference of this on desflurane MAC.

Although a decrease in body temperature was observed from the start of anesthetic administration until the end of experimental period, all the values were maintained within a range considered normal for species (Haskins, 1997). Through the use of a heating pad, which minimized possible interferences of hypothermia, such as reduction of partial pressure of oxygen, increase of solubility, deflection to left of oxyhemoglobin dissociation curve, hindering liberation of oxygen to tissues (Yazbek, 2002), increase of anesthesia recovery period and solubility and tensions of blood gases. In addition, it is known that hypothermia reduces MAC of inhalant anesthetics (Eger II, 1992).

Thus, results obtained with the proposed methodology allow to conclude that addition of nitrous oxide to desflurane reduced its MAC by $16 \%$. This association also induced an increase in $\mathrm{HR}$ and a considerable respiratory depression in dogs. 


\section{REFERENCES}

ALLAOUCHICHE, B.; DUFLO, F.; DEBON, R. et al. Influence of sepsis on minimum alveolar concentration of desflurane in a porcine model. Br. J. Anaesth., v.87, p.280-283, 2001.

AMARAL, J.L.G. Anestesia inalatória. In: YAMASHITA, A.M.; TAKAOKA, F.; AULER JUNIOR, J.O.C. et al. (Eds.). Anestesiologia SAESP. 5.ed. São Paulo: Atheneu, 2001. p.551577.

CAHALAN, M.K.; WEISKOPF, R.B.; EGER II, E.I. et al. Hemodynamic effects of desflurane/nitrous oxide anesthesia in volunteers. Anesth. Analg., v.73, p.157-64, 1991.

CLARKE, K.W.; ALIBHAI, H.I.K.; LEE, Y.H. et al. Cardiopulmonary effects of desflurane in the dog during spontaneous and artificial ventilation. Res. Vet. Sci., v.61, p.82-86, 1996a.

CLARKE, K.W.; SONG, D.Y.; ALIBHAI, H.I.K. et al. Cardiopulmonary effects of desflurane in ponies, after induction of anaesthesia with xylazine and ketamine. Vet. Rec., v.139, p.180-185, 1996 b.

EGER II, E.I. Desflurane animal and human pharmacology: aspects of kinetics, safety, and MAC. Anesth. Analg., v.75, p.3-9, 1992.

EGER II, E.I.; BRANDSTATER, B.; SAIDMAN, L.J. et al. Equipotent alveolar concentrations of methoxyflurane, halothane, diethyl ether, fluroxene, cyclopropane, xenon and nitrous oxide in the dog. Anesthesiology, v.26, p.771-777, 1965.

EGER II, E.I.; JOHNSON, B.H.; WEISKOPF, R.B. et al. Minimum alveolar concentrations of I653 and isoflurane in pigs: definition of a supramaximal stimulus. Anesth. Analg., v.67, p.1174-1176, 1988.

FAUROUX, B.; CORDINGLEY, J.; HART, N. et al. Depression of diaphragm contractility by nitrous oxide in humans. Anesth. Analg., v.94, p.340-345, 2002.

FISHER, D.M.; ZWASS, M.S. MAC of desflurane in $60 \%$ nitrous oxide in infants and children. Anesthesiology, v.76, p.354-356, 1992.

GOLD, M.I.; ABELLO, D.; HERRINGTON C. Minimum alveolar concentration of desflurane in patients older than 65yr. Anesthesiology, v.79, p.710-714, 1993.

GRUNDMANN, U.; MULLER, M.; KLEINSCHMIDT, S. et al. Cardiovascular effects of desflurane and isoflurane in patients with coronary artery disease. Acta Anaesthesiol. Scand., v.40, p.1101-1107, 1996.

HAELEWYN, B.; ZHU, L.; HANOUZ, J.L.; et al. Cardioprotective effects of desflurane: effect of timing and duration of administration in rat myocardium. Br. J. Anaesth., v.92, p.552-557, 2004.

HAMMOND, R.A.; ALIBHAI, H.I.K.; WALSH, K.P. et al. Desflurane in the dog: minimal alveolar concentration (MAC) alone and in combination with nitrous oxide. J. Vet. Anaesth., v.21, p.21-23, 1994.

HASKINS, S.C. Termorregulação, hipotermia, hipertermia. In: ETTINGER, S.J.; FELDMAN, E.C. (Eds.). Medicina interna veterinária. 4.ed. vol. 1. São Paulo: Manole, 1997. p.33-39.

HOHNER, P.; REIZ, S. Nitrous oxide in the cardiovascular system. Acta Anaesthesiol. Scand., v.38, p.763-766, 1994.

HORNBEIN, T.F.; EGER II, E.I.; WINTER, P.M. et al. The minimum alveolar concentration of nitrous oxide in man. Anesth. Analg., v.61, p.553$556,1982$.

KERBAUL, F.; RONDELET, B.; MOTTE, S. et al. Isoflurane and desflurane impair right ventricularpulmonary arterial coupling in dogs. Anesthesiology, v.101, p.1357-1362, 2004.

LOCKHART, S.H.; RAMPIL, I.J.; YASUDA, N. et al. Depression of ventilation by desflurane in humans. Anesthesiology, v.74, p.484-488, 1991.

MCMURPHY, R.M.; HODGSON, D.S. Cardiopulmonary effects of desflurane in cats. Am. J. Vet. Res., v.57, p.367-370, 1996.

MOYLE, J.T.B.; HAHN, C.E.W.; ADAMS, A.P. Pulse oximetry: principles and practice series. London: BMJ, 1994. 134p.

MUTOH, T.; NISHIMURA, R.; SASAKI, N. Effects of nitrous oxide on mask induction of anesthesia with sevoflurane or isoflurane in dogs. Am. J. Vet. Res., v.62, p.1727-1733, 2001.

NICKALLS, R.W.D.; MAPLESON, W.W. Agerelated iso-MAC charts for isoflurane, sevoflurane and desflurane in man. Br. J. Anaesth., v.91, p.170174, 2003. 
NUNES N. Monitoração da anestesia. In: FANTONI, D.T.; CORTOPASSI，S.R.G. (Ed.). 1.ed. São Paulo: Roca, 2002. p.64-81.

NUNES, N.; MARTINS, P.S.P.; SANTOS, M.L. et al. Effects of desflurane, sevoflurane and isoflurane on pulmonary shunt in dogs during spontaneous ventilation. Arq. Bras. Med. Vet. Zootec., v.55, p.173-177, 2003.

NUNES, N.; SANTOS, P.S.P.; VICENTI, F.A.M. et al. Efeitos da associação de fentanil e droperidol na concentração alveolar mínima do desflurano, em cães. Ars Vet., v.17, p.86-92, 2001.

PARK, K.W. Cardiovascular effects of inhalation anesthetics. Inter. Anesth. Clin., v.40, p.1-14, 2002.

PATEL, S.S.; GOA, K.L. Desflurane: a review of its pharmacodynamic and pharmacokinetic properties and its efficacy in general anaesthesia. Drugs, v.50, p.742-767, 1995.

PICKER, O.; SCHWARTE, L.A.; SCHINDLER, A.W. Desflurane increases heart rate independent of sympathetic activity in dog. Eur. J. Anaesth., v.20, p.945-51, 2003.

PIRIOU, V.; CHIARI, P.; LHUILLIER, F. Pharmacological preconditioning: comparison of desflurane, sevoflurane, isoflurane and halothane in rabbit myocardium. Br. J. Anaesth., v.89, p.486491, 2002.

RAMPIL, I.J.; LOCKHART, S.H.; ZWASS, M.S. et al. Clinical characteristics of desflurane in surgical patients: minimum alveolar concentration. Anesthesiology, v.74, p.429-433, 1991.

REZENDE, M.L.; NUNES, N.; MARTINS, S.E.C. et al. Minimum alveolar concentration of desflurane in dogs pretreated with levomepromazine. Ars Vet., v.20, p.314-321, 2004.
SPONHEIM, S.; SKRAASTAD, O.; HELSETH, E. et al. Effects of 0.5 and 1.0 MAC isoflurane, sevoflurane and desflurane on intracranial and cerebral perfusion pressures in children. Acta Anaesthesiol. Scand., v.47, p.932-938, 2003.

STEFFEY, E.P. Inhalation anesthetics. In: THURMON, J.C.; TRANQUILLI, W.J.; BENSON, G.J. (Eds.). Lumb \& Jones' veterinary anesthesia. 3.ed. Philadelphia: Lea \& Febiger, 1996. p.297-329.

STENQVIST, O.; HUSUM, B.; DALE, O. Nitrous oxide: an ageing gentleman. Acta Anaesthesiol. Scand., v.45, p.135-137, 2001.

VALVERDE, A.; DYSON, D.H.; MCDONELL, W.N. Epidural morphine reduces halothane MAC in the dog. Can. J. Anaesth., v.36, p.629-632, 1989.

WARNER, D.O.; WARNER, M.A.; JOYNER, M.J. et al. The effect of nitrous oxide on chest wall function in humans and dogs. Anesth. Analg., v.86, p.1058-1064, 1998.

WYLIE, W.D.; CHURCHILL-DAVIDSON, H.C. Os gases anestésicos. In: WYLIE, W.D.; CHURCHILL-DAVIDSON, H.C. (Eds.). Anestesiologia. 3.ed. Rio de Janeiro: Guanabara Koogan, 1974. p.184-195.

YAZBEK, K.V.B. Hipotermia. In: FANTONI, D.T.; CORTOPASSI, S.R.G. (Eds.). Anestesia em cães e gatos. 1.ed. São Paulo: Roca, 2002. p.373378.

ZWASS, M.S.; FISHER, D.M.; WELBORN, L.G. et al. Induction and maintenance characteristics of anesthesia with desflurane and nitrous oxide in infants and children. Anesthesiology, v.76, p.373378, 1992. 